\title{
(Wo)monstrous suturing: Woman doctoral students cutting together/apart
}

\author{
Stephanie Anne Shelton, Ph.D., Assistant Professor, Qualitative Research, University of Alabama, USA, \\ e-mail sashelton@ua.edu \\ Kelly W. Guyotte, Ph.D., Assistant Professor, Qualitative Research, University of Alabama, USA, \\ e-mail kwguyotte@ua.edu \\ Maureen A. Flint, Ph.D., Assistant Professor, Qualitative Research, University of Georgia, USA, \\ e-mail maureen.flint@uga.edu
}

\section{Abstract}

This paper centers the experiences and understandings of women doctoral students during two separate focus groups and collaborative collages. (Re)theorizing "monsters" as "intra- sectional" through Karen Barad's and Kimberlé Crenshaw's scholarship, we (re)position the "monstrous" as agentive and self-creative concepts. We explore the concept of (wo)monsters and the (wo)monstrous: empowered women participants who, through their verbal and artistic participations, cut themselves, others, and the group together/apart. In making these cuttings, they worked to (re)suture themselves and their group(s) back together in (re)generative, (wo)monstrous ways. The women's participations emphasized their (wo)monstrosities as affirmingly fantastical, imagining new ways of being and wreaking havoc on hegemony and hierarchy.

Keywords: Women in academia, doctoral students, focus groups, arts-based research, intra-action, intra-sectionality 
"The monster always represents the disruption of categories, the destruction of boundaries, and the presence of impurities and so we need monsters and we need to recognize and celebrate our own monstrosities." (Halberstam, 1995, p. 27)

\section{Monstrosities and Intra-sectionality}

"Monster" conjures images of fire-breathing, winged, fantastical creatures lumbering through the countryside, wreaking havoc and destruction. Monsters are generally imagined to be bad, scary, dangerous, or at the very least, to-be-avoided. However, Karen Barad (2015), borrowing from Jack Halberstam's (1995) queer studies work, imagines monsters and monstrosities in a wholly new way-centering women as politically charged, empowered, self-generative beings. Although being understood as monstrous "can serve to demonize, dehumanize, and demoralize," being a monstrosity "can also be a source of political agency. It can empower and radicalize" (Barad, 2015, p. 392). In this paper, we examine two focus group intra-actions between doctoral student women to (re)imagine (wo)monstrosities as means of centering women's identities and experiences through an intraactive methodological emphasis on researcher response-ability. These focus group intra-actions "embrace[d] the would-be epithet of monstrosity, harnessing its energy and power [to] transform despair and suffering into empowering rage, selfaffirmation, theoretical inventiveness, political action, and energizing vitality" (p. 392). Through the focus groups, women doctoral students became affirmingly fantastical-imagining new ways of being, while wreaking havoc on hegemony and hierarchy.

\section{(Wo)Monstrous Ethical Responsibility and Vulnerability}

Because the focus groups on which this research was based involved women doctoral students, we begin here by considering the ways that scholarship has discussed women in academia. Consistently, literature has demonstrated the degrees to which women doctoral students are cut together/apart as they move through their educational trajectories. Often, these cuttings occur through the academy's reification of traditional gender roles. For example, women doctoral students, and women in academia in general, balance contradictory and multiple roles throughout their programs, including a multitude of gendered negotiations relative to family and other relationships. Gregor (2015) described the how gendered norms and sexism directly tied women's opportunities for academic leadership to the degrees to which they chose career over family. Their study found that greater emphasis on family equated to limited professional promotions and vice versa (see also Bireda, 2015; Holm, Prosek, 
\& Godwin Weisberger, 2015; Wolfinger, Mason, \& Goulden, 2009). Other research has demonstrated that women have substantially less job security and hold fewer leadership roles in academia (Abetz, 2016; Morley, 2013). Enacting further cuts, the literature often constructed these negotiations in problematic terms that framed women as (part of) the problem, or as selfsacrificing martyrs (e.g., Kurtz- Costes, Helmke, \& Ulku-Steiner, 2006; Mansfield, Welton, Lee, \& Young, 2010). Thus, the literature has demonstrated that women are navigating complicated and gendered paths through their doctoral programs, while it has simultaneously reaffirmed the binaries of these negotiations as cut between student and family.

\section{Intersections of Identity}

Within the literature, there were substantial discussions examining the experiences of either women or students of color in doctoral programs, but few studies that considered the intersectional experiences of women of color in these spaces (Aryan \& Guzman, 2010). Research that has explored women of color's experiences in doctoral programs often described feelings of isolation and lack of understanding from peers and faculty (Grant, 2012; Grant \& Simmons, 2008; Magano, 2011). Though there was evidence indicating the value of mentorship and support for women of color (Grant, 2012; Grant \& Simmons, 2008; McKinley, 2014; Pope \& Edwards, 2016), the fact remains that academia makes it difficult to find such support systems, especially from women faculty of color, who are underrepresented in tenure-track and tenured positions (Marbley, Wong, Santos-Hatchett, Pratt, \& Jaddo, 2011; Turner, 2002; Zahneis, 2018). Though race was taken up limitedly, discussions of age(ism) in academia were even less common. Although some research considered age as a factor when earning a doctoral degree (e.g., Miller, 2016), those discussions rarely featured a woman unless the age difference was extreme, such as a news story featuring an 88-year-old woman earning a PhD (Kyodo, 2018).

The women doctoral students in this research described a multitude of identities, including age, race, and gender, as significant to their experiences and their research foci. However, an extensive review of doctorate recipients in the United States by the National Science Foundation (NSF) (2018) made no mention of students' age. And while both gender and race were considered factors, the same study did not intersect the two to explicitly include women of color. This extensive NSF study reflects the pervasiveness in which women's career trajectories have been cut apart by gender roles, while also signaling the problems of identity intersections, such as women of color and older women in doctoral programs being cut out almost completely. 


\section{Doctoral Women and Identity}

As we examined literature on doctoral women and their multifaceted identities, we noted that although there was substantial scholarship referencing women's identities, few studies understood identity to be something dynamic, and over which women had agency. Instead, many studies used women's identities as the basis of programmatic change, with identity serving as a static concept/impetus that then drove policy making (e.g., Batruni, 2018; Khattak, 2018; Wu \& Wu, 2015). In other instances, identity served as the basis of examining gender-based discrimination, but with no clear sense of agency for the women included in the research (e.g., Kelly \& McCann, 2019; Yeh, 2018). Another research focus was on identity building, but with women grouped into general discussions of higher education, rather than explorations of gendered identities (e.g., Angervall \& Silfver, 2019; Catterall, Mickenberg, \& Reddick, 2019; Holley, 2015).

Building from previous research, participants in this study examined the multiple binds that they faced as a result of gender inequality in higher education, and considered how their multiple identities-including gender, race, and age-mattered in those experiences. Their discussions expand the existing literature to include intersectional considerations of women's doctoral trajectories. Additionally, this paper seeks to theorize identity in new ways. We discuss identity as dynamic, constantly (co)constructed, and a potential source of agency and empowerment for women, while considering the implications for these (wo)monstrous identities in a field where women are often cut out/on.

\section{Intra-sectional (Wo)Monstrosities}

Stirred by the cuts between identities that the participants in the study described, we conceptualize their intra-actions as (wo)monstrous. We follow threads of agency and connection to examine how a response-able methodological stance encouraged women doctoral students to use focus group intra-actions to become "monstrous" to themselves and others in their decisions, lives, and/or identities. Specifically, we looked at how women doctoral students used the methodological spaces of focus groups and collaborative collaging to reconfigure their (wo)monstrosities into agentive and empowered (re)creations. After an open call across a research-intensive university campus in the southeastern United States, 19 doctoral student women, all earning degrees in education or communications, enrolled in this project. Though the study was open to any womanidentifying doctoral students, all participants identified as cisgender, and all identified as heterosexual. Five self-identified as Black women, one as a multiracial Black woman, one as a Native American woman, and 12 as White women. Seven were 
mothers, seven described themselves as "older, non-traditional" students because they were 40 years old or older, and one was an international student. There were also us, three women researchers. Maureen is a White, cisgender, heterosexual woman who, during the research, was also a doctoral student. Kelly and Stephanie are early-career faculty members. Kelly is White, cisgender, heterosexual, and a mother; Stephanie is a White, cisgender, queer lesbian. In an effort to better represent these multifaceted and intra-secting identities, Table 1 lays out the multiple categories that these (wo)monsters deemed relevant and discussed throughout their participations. These 22 women-19 participants and three researchers-found their multiple identities and experiences meaningfully entangled individually and collectively throughout the research. However, the two focus groups that we examine here, which involved 13 of the participants (five in one; eight in another) and all three researchers, involved conversations and collaging that were particularly powerful/empowering intra-actions.

We initially planned to have a single large focus group, which would have included all 19 participants. However, participants' responses to our scheduling inquiries made it clear that there was no one day that worked best for everyone. Numerous gendered realities, including childcare, tending to home responsibilities after a workday, and caring for aging parents crept into any attempts to schedule a single large group discussion. Therefore, to include as many participants as possible, we broke the original one large focus group into two smaller ones in order to accommodate participants' lives and availability. During these two meetings, women (dis)splayed multiple (wo)monster selves for/to the other (wo)monstrous participants and us; they cut and (re)configured themselves together/apart to (re)create and (re)imagine the(ir) (wo)monstrousness as both affirmed and affirming. (Wo)monstrous concepts are/were/will be necessarily intra-actional (Barad, 2013). Intra-action, in both Barad's (2007) work and our exploration, "signifies the mutual constitution of entangled agencies" (p. 33), which both considered the ways that relationships, identities, spaces, and other elements were inseparable, and rejected the notion that these entities were ever isolated or stable. Efforts, then, to (re)define the "(wo)monster" were inevitably entangled in flesh, shared/individual experiences, spaces, memories, and other beings. These (re)configurations were iterative becomings that (re)traversed people, places, things, and moments to (re)create new and powerful notions of (wo)monsters.

Importantly, Barad (2015) asserted that (re)composing monstrosities is always/only politically charged and socio-politically contextualized. Orienting to the situated politics of (re)composition, these (wo)monster participants understood themselves and their intra-actions as constantly intersectional. They described themselves as patchworks of multiple, ever-intersecting identities; different pieces of their selves mattered in different ways, in different moments, but the pieces always/already mattered. For example, participants who identified as women of color-who described race simultaneously as a social 
construction and daily experience- experienced womanhood as constantly racialized, by themselves and others; thus, the ways that they might have been deemed "(wo)monstrous" were necessarily/simultaneously/dynamically entangled in gender and race.

To honor and center these intersectional (wo)monstrous identities, we position Barad's monstrous theorizing alongside Kimberlé Crenshaw's (1989; 2004) groundbreaking work on intersectionality. Crenshaw's concept of intersectionality emphasized the ways that women's multidimensional identities, including elements such as race, socioeconomic class, sexuality, and age, occur in relation, creating simultaneous sites of social privilege and oppression. Crenshaw's work might seem misaligned with Barad's, primarily because Barad's work explores identity as unstable and shifting, and Crenshaw's emphasizes power structures and inequalities rather than identity formation. However, a beginning point for intra-secting Crenshaw with Barad is the degrees to which both understand identity as constructed. Certainly, Barad's monstrosities are a different creation process than Crenshaw's considerations of socio-political structures, but both scholars theorize ways in which individuals shape and are shaped by their contexts, and the ways that those shapings might be (dis)empowering. For example, Crenshaw (1991) pointed out that "identity politics is problematic, fundamentally because the violence that many women experience is often shaped by other dimensions" (p. 1242). She noted that ignoring the degrees to which these different dimensions matter at different times silences women and relegates them "to a location that resists telling" (p. 1242). For Crenshaw, identities have never been comprehensive or complete, and the tendencies for scholars to treat them as such "only highlights the need to account for multiple grounds of identity" (p. 1245).

Certainly, Crenshaw's understanding of identity is less theoretically fluid than Barad's. However, to understand Crenshaw's work as positioning identity as wholly stable is to dismiss the degrees to which Crenshaw explored the social constructed-ness and contextually-bounded elements of identities. In discussing rape and sexual violence, for example, Crenshaw (1991) discussed gender and race as facts, but only after offering detailed considerations of how racialized gender and gendered race necessitated historical considerations of how race and womanhood have been crafted and used by various groups, and the ways that those uses have adapted through time. Thus, it is less that identity is stable for Crenshaw, than it is that the real- life implications of identity-based oppressions are constant. Though theorizing from different paradigms, Crenshaw and Barad are less oppositional and more complementary in the ways that they understand identity to be complex, contextually-informed, and directly tied to sites of oppression and possibilities of empowerment.

Reconceptualizing Educational Research Methodology 2019, 2,3(2) Special Issue

https://journals.hioa.no/index.php/rerm/issue/view/397 
In terms of empowerment, Crenshaw (1991) noted that when women collectively explore systemic inequalities, they render those oppressions visible while centering women's unique sites of oppression. Group considerations of women's experienced inequities demonstrate the pervasiveness of what was previously "perceived as isolated and individual" through collective critiques (p. 1242). Additionally, open dialogue within presumably similar groups, such as focus groups of women in our research, challenges tendencies to "conflate or ignore intragroup differences," while emphasizing that women's individual and shared understandings are shaped by multidimensional and politicized experiences (p. 1242).

With monstrosities and intersectionality as guiding concepts, then, our work intentionally centered the theoretical works of two women scholars who have written from the margins of academia. Crenshaw, a Black cisgender woman in legal studies, has created scholarship emphasizing the ways that intersecting identity elements have shaped individuals' access to equity and justice. Barad, a queer White woman who embraced Crenshaw's intersectionality as a core concept of her theorizing (e.g., Barad, 2014), used her expertise in quantum physics to extend feminist explorations of time, space and matter. She examined the ways that the constant intra-connectedness of space, time, and matter have shaped individuals' agency within and understandings of their contexts. Therefore, although Crenshaw and Barad write from different perspectives, their combined emphases on feminist thoughts and women's empowerment offer new possibilities to feminist and higher education scholarship, and guide our discussion and analysis.

We build from their theorizations to understand (wo)monstrosity as simultaneously intra- active and intersectional. In doing so, we use the terms "intra-sectional" and "intra-sectionality" throughout this paper. The term "intra-sectionality" nods to both Crenshaw and Barad and acknowledges the multiplicities of identities with/in intra-action. It is impossible to separate or individuate these multiple identities in their "iterative intra-active becoming - not a thing, but a doing, a congealing of agency" (Barad, 2013, p. 17). Elements such as race and gender are always/only entangled, and considerations of women's experiences are made richer through acknowledging/interrogating the ways that these multiple identities matter to the participants, their co-participants, and the researchers. The (wo)monstrousness of these participants' intra- sectional explorations actively worked to disrupt their own and others' notions of self, of womanhood, and of doctoral studies in efforts to (re)define their presumed monstrosities as agentive, feminist, and empowered. 


\section{Ethico-Onto-Epistemology, Response-ability, and (Wo)Monsters}

As noted previously, this paper examines focus group intra-actions. However, before describing the focus groups themselves, an integral aspect of this research has been the ethics guiding our methodology. Our understandings and enactment of research ethics was informed by Barad's (2007) discussion of ethico-onto-epistemology and Haraway's (2008) and Barad's (2007) notions of research(er) response-ability. Since its inception, our research with women in doctoral programs has worked to counter extant scholarship's cutting/sawing/slicing with a more agentive and intra-sectional examination of women's efforts to cut together/apart. Barad (2015) celebrated that "the promise of monsters" is one that is regenerative and rife with possibility (p. 407); however, she also noted that cutting together/apart is an act that carries substantial vulnerability and considerable ethical implications (Barad, 2014). These participants' (wo)monstrous explorations and shifts reimagined education and research-based interactions, while necessarily "put[ting] the story-teller[s] at risk" (Barad, 2013, p. 17). It was the participants' willingness to self-dissect, to cut and to suture together/apart, that made these research intra-actions so meaningful/powerful for the participants and to us, the researchers, and that made this ethico-onto-epistemology so necessary.

\section{Ethico-Onto-Epistemology and Response-ability in Research}

Barad (2007) explained that ethico-onto-epistemology is "an appreciation of the intertwining of ethics, knowing, and being" ( $p$. 185). Within the two focus groups, we recognized that "we are not merely differently situated in the world; 'each of us' is part of the intra-active ongoing articulation of the world in its differential mattering" (p. 381). As researchers, then, we were constantly mindful of the presumed boundaries between ourselves and participants, between participants themselves, and between the three of us. These boundaries were both material in the ways that each had experienced womanhood and doctoral studies, and perforated due to the inevitably tangled nature of focus group intra-actions. We navigated a complex ethical space. The participants shared some commonalities, but they initially understood themselves to hold separate/individual lives/experiences. Through facilitating the large focus group, we were asking them to puncture those separations, and to be vulnerable enough to share the inevitably messy and gendered aspects of their educational experiences. And, our ultimate hope was that these openings between/among them would be generative and empowering intra-actions for all.

Research is not generally viewed as empowering, given the innate power differentials that exist between researchers and researched. Certainly, those inequalities remained here, but we designed this project to provide spaces for marginalized and 
oppressed voices to be heard and valued. While there was nothing inherently magical about such an approach, it offered opportunities-which these women remarked on throughout the research project-for these participants to be heard by and entangled with one another and us. Such efforts explicitly assert feminist, woman-centered scholarship. Barad (2014) noted that these "entanglements require/inspire a different sense of a-count-ability, [...] a different calculus of response-ability" (p. 178). Haraway (2008; 2016), who informed Barad, explained that response-ability involves researchers working to provide a "praxis of care and response," with researchers actively attending and responding to participants' everyday stories (Haraway, 2016, p. 105). And, both Haraway and Barad note that stories are critical to response-ability, that "there are quite definitive responseabilities that are strengthened in such stories" (Haraway, 2016, p. 115).

This concept of response-ability is an inevitable aspect of ethico-onto-epistemology. Response-ability was enacted through intra-actions, including participants' hesitant tears and ringing laughter. Response-ability was a decision on our part to understand and participate in our research as a collective experience. We were necessarily involved in their stories and in the cutting and suturing apart/together that characterized their intra-actions. Not just acknowledging but celebrating these involvements were key to the ways that we, as researchers, understood the ethical implications of and enacted this research that centered women doctoral students.

Response-ability was an entangled concept, as both researchers and participants intra-acted through/with/because of "thick tangles of spacetimematterings that were threaded through us, the places and times" that we brought with us to the research project, and that we co-created during the focus groups (Barad, 2014, p. 184). Being response-able was multifaceted-it was both taking responsibility for the implications of engaging with explorations with/through/because of others, and literally feeling/being able to respond-feeling/being empowered enough to speak and to be heard.

\section{Enacting Response-ability}

Response-able work was/is complex, and we three were mindful of the ways that our research decisions shaped the degrees to which women could/would be response-able with us. For example, these two focus groups occurred at the end of our data generation. We had preceded this stage with individual interviews and four smaller focus groups, intended to provide opportunities for women to share and feel heard one-on-one and with a smaller, more intimate group, before asking them to be open and vulnerable within a larger group setting. Imagining and planning these focus groups, we revisited each of those earlier 
intra-actions and considered what threading and cutting the women had described/performed previously. We paid particular attention to ways that women felt silenced or empowered, both in their remembered experiences, and in relation to other bodies and materialities in the intra-active spaces of the interview/small focus groups. In response, we began each large focus groups with an invitation for participants to take the lead and thereby make our participation as researchers minimal and unnecessary, while readily inviting the women to acknowledge/examine our presence. Feeling response-able, both empowered to take responsibility for the focus group as well as to respond, the women took over the flow of intra-actions. Over the course of approximately two hours in both instances, we collectively posed roughly five questions. Instead of guiding the discussion, there were instead moments when the women, suturing their (wo)monstrous selves, applied the needles and threads to us. In the first focus group, for example, Grace asked the others to contemplate to what degree their prior knowledge of and relationships with the three of us had shaped their willingness to participate in both the study and the focus group. In the second group, Raquel emphasized one researcher's visible pregnancy to pose a question about the ways that family and childbearing had informed participants' doctoral experiences. In short, we were not permitted to be detached scientists, observing formed (wo)monsters according to a particular agenda; instead, we were brought onto the examination tables and into the laboratory with them, becoming cut together/apart as part of the research process. Certainly, power differentials remained, and we do not pretend that we fully mitigated the disparities typical of the research process, but these women's response-abilities guided the intra-actions in ways that created anew and drew us into those sutures. Becoming (wo)monstrous together/apart with response-ability.

\section{Connected to the World through Ethico-Onto-Epistemology and Response-ability}

Our efforts to foster participant response-ability also centered intra-sectionality as a core concept, to necessarily encourage intra-actions that acknowledged and valued multiplicitous identities/experiences and explored difference in meaningful ways. Though we posed few questions, we did start both of these focus groups by asking the women how various political shifts that accentuated identity/community-based inequalities/activisms, including \#BlackLivesMatter, \#MeToo, and \#TransLivesMatter, had possibly shaped their experiences in their doctoral programs. On the heels of the Brett Kavanaugh hearing in the United States, as well as an ongoing national climate where issues surrounding sexual assault were centered in the national news, we could not cut ourselves from the outside world. An ethico-onto-epistemology necessarily recognizes the constant entanglements and collisions of (wo)monsters with the world. There is never a separation or an opportunity to engage as a bystander; instead, these politics and discourses mattered to us individually and collectively. Barad (2010) wrote of intra-active 
response-ability, "It is an iterative (re)opening up to, an enabling of responsiveness [...] through the iterative reworking of $\mathrm{im} /$ possibility, an on-going rupture" (p. 265). The group's intra-sectionalities echoed this (re)working, forming a constant weaving of self/other that cut together/apart in empowering ways. Tamara, for example, began the second focus group by specifically considering the ways that doctoral studies had introduced her to Black Feminism. Rather than cutting her apart from the group, her intra-sections of gender and race prompted others to explore both their own inter-secting identities and those of others. Likewise, Anna readily engaged with her Whiteness as a site of substantial privilege, even as she noted the degrees to which her own visible pregnancy and womanhood limited other possibilities in academia.

The response-able intra-sections brought forth by the women proved to be "a regenerative politics, an invitation to explore new ways of being in touch, new forms of becoming, new possibilities of becoming, new possibilities for kinship, alliance, and change" (Barad, 2015, p. 410). The intimate, restorative, agentive intra-action that took place during the focus groups is, as Barad (2015) described, "[t]he promise of monsters" (p. 410), and these (wo)monsters' response- abilities enabled them to examine individual identities/experiences in supportive ways and to make the research intra-actions, as one of our participants, Yvonne, put it, "about love."

\section{Focus Groups: Sites of (Wo)Monstrous Creations}

This (wo)monstrous research was conceived following Stephanie and Kelly's experiences as faculty and mentors with multiple women doctoral students. Time after time, they found themselves viscerally affected as women tentatively knocked during office hours and ultimately shared their frustration and anger with the many difficulties they were encountering in pursuing their doctoral degrees, accompanied by quavering voices and often tears. At one point, for example, Stephanie sat in her office, as a sobbing doctoral student, hands shaking and tears streaming, described how a male faculty member had suggested that the student get an abortion rather than be pregnant while earning her PhD. He had asserted the impossibility of her academic/professional success coinciding with her decision to have a child. The conversation had ended with contacts to various gender resource offices at the university, but the raw emotion and humanity of the moment lingered. And, though this moment was more extreme than most, visits from women doctoral students reporting heavily gendered moments in their degree trajectories were near-daily. For Stephanie and Kelly, as well as Maureen, who was in her doctoral program at the time, the concerns and experiences of these students resonated with their own experiences as women in doctoral programs. It was in response to the reverberations of these shared aches, cries, and shouts that this study came to be. 
This paper draws from a larger study that examined women doctoral students' experiences navigating gendered lives/experiences within/beyond the academy. As noted earlier, the participants were 19 women pursuing doctoral degrees at a research-intensive university in the southeastern United States. Over the course of the project, all (wo)monsters participated in an individual interview, and nearly all participated in both a small focus group of 2-4 women and a large focus group of 5-9 women. Focusing on the two large focus group intra-actions, including images from intra-actively constructed collages during those focus groups, this paper is guided by the research question,

How do women doctoral students describe the cutting together/apart of selves as intra-sectional?

Guided by this research question, we three met to revisit the two final focus groups and to (re)member ways that the intraactions had done the theoretical work of cutting together/apart.

We made notes based on our memories, as we all three had been present during both focus groups, so that we would have starting points when returning to the audio recordings of the intra-actions. We then set up a shared document, where each of us transcribed the audio and made notes on one another's efforts. Because we understood the transcriptions to be coconstructed and a continued part of the cutting together/apart (Shelton \& Flint, 2019a; 2019b), we consistently shared and checked in with one another, and shared our efforts with participants. Certainly this sharing was part of the more standard member checking, but for us, it was a continuation of the entangled ethico-onto-epistemology of response-ability: they and we were always/only connected through this research, and it was important that they be included in the data production. After we had transcribed from the audio, we began to collaboratively organize the now-written data and draft the manuscript based on the research question.

We shared the in-progress draft with participants-with the explanation that we planned to submit the paper for publicationand waited several weeks for them to respond back with any feedback or questions. Though previous research member checking on other projects had taught us to expect few or no responses, these women remained invested in this project, and consistently replied. In most instances, the comments were celebratory, with appreciation for the ways that the theoretical notions of cutting apart/together seemed to capture many of what they deemed the most important aspects of the focus groups. In a few instances, participants clarified or questioned our interpretations, such as a moment when we discussed the groups' collaging activities, and a participant more fully clarified what she meant when she had added text to one of the 
collage's images. In these moments, we discussed their concerns with them and made edits accordingly-continuing the shared suturing and cutting that had characterized the research since the beginning.

The intra-sectional participations of the (wo)monsters during the large focus groups emphasized the ways in which they felt torn apart as women in academia by the gendered expectations placed on them by family, friends, society, and selves - and the ways that they used their intra-sectional intra-actions and their senses of empowerment throughout the research process to piece themselves together in new, empowered ways. The women doctoral students in this study embraced the (wo)monstrousness of woman-as-academic, while cutting together/apart the seeming disparate pieces of womanhood and academia to agentively patchwork together new selves/beings. In what follows, we turn to the first focus group and then the second as sites where (wo)monstrous academic women cut together/apart the seeming disparate pieces of womanhood and academia, and began to agentively patchwork together new selves/beings.

\section{Patchworking: Cutting Together/Apart (Wo)Monsters}

During the first large focus group of the study, seven women sat in a circle contemplating a question from Stephanie about the ways that contemporary politics shaped their identities and doctoral studies. Valencia ${ }^{1}$, a self-identified multiracial Black woman, initiated the discussion by telling the group, "Being a woman of color, I'm terrified for women, for the LGBTQ community, for Black people, just for everyone." She examined the ways that her identities as a woman of color, as a mother, and as a daughter intra-sected with her identity as a scholar and afforded her opportunities to learn from and generate "research [that] talks about underrepresented people." As she did so, she emphasized that-particularly in the present political climate-her experiences, generated from many, constantly colliding historically marginalized identities, "is just overwhelming."

Janna, a White woman, agreed with Valencia's sentiments but, in relation to her own unique identities, instead emphasized, "I feel my biggest role is a mother" and worried "how the world will affect them [her children]." Yvonne, also a White woman, drew on her identities as an international student and teacher, to agree, "What's happening outside [the university] is influencing me." Picking up the shared group thread of concern for society and self, Hope, a White woman, drew from her

${ }^{1}$ All names are pseudonyms; most participants choose to select their own pseudonyms.

Reconceptualizing Educational Research Methodology 2019, 2,3(2) Special Issue

https://journals.hioa.no/index.php/rerm/issue/view/397 
experiences in working with adults with disabilities, noting the ways that her own doctoral journey was different from the others', while similarly maintaining the importance of being politically aware and active while in "this bubble" of academia. The intra-sectional discourse between the women provided a space that Valencia noted was unusual, in that she felt seen and heard. In other words, the experience of the focus group stood in contrast to other experiences the women shared from their doctoral programs, where they described efforts to become visible. Yvonne echoed Valencia's reflection, emphasizing that the space of the focus group was one that resonated with hope and care between the women participants.

Then Grace, who had remained silent during the first half hour of the group's exchange, spoke. Stammering and clearly nervous, Grace said: "I don't think they're [people in academia or media outlets] representing women or races, or genders, or transgender well." Several of the other women nodded in agreement. She stopped to take a deep breath, the visible parts of her neck and chest breaking out in red splotches, visual indications of her anxiety. Voice shaking, she continued,

I'm much older than others here. And, as someone very much your senior and as a Southern Christian conservative woman, I'm silenced in academic spaces. I'm put down for it. I feel censored. I have a very different perspective than all of you.

Before Grace's participation, the women had easily aligned with one another, even as they acknowledged differences in racial identities, research interests, and family backgrounds. Now, there was a palpable pause in the group as the other women weighed how they would respond toGrace, who had assertively positioned herself as an outsider in terms of both her age and religious-political views.

Barad (2015) notes that "monstrous re/generations" are made up of "multiple im/possibilities that coexist and are iteratively intra-actively reconfigured" (p. 388). In this moment, Grace asserted the impossibility of her place in the group-a group that had celebrated its supportive knit of intra-actions, just before she worked to cut herself from its fabric. Because the concept of (wo)monster is necessarily, dynamically intra-sectional, the group acknowledged Grace's efforts to tear herself from them and their positionalities, but then shifted to exploring the (wo)monstrous "agential capacities for [...] imagining together [...] creating new political imaginaries and new understandings" (p. 388). In response to Grace's cutting apart, it was Janna who began the work of cutting and stitching back together. 
Taking up the threads of Grace's sense of religion-based ostracization, Janna shared with the group, "I'm an atheist, and people write me off as a heathen." She continued, describing how she was very conscientious of what parts she shared of herself in new or unwelcoming spaces.

Although Janna offered a perspective that seemed, spiritually, in direct conflict with Grace's, her willingness to share her own (im)possibilities of existing within the group shifted the tearing Grace had initiated to one of cutting together/apart. Grace and Janna's stories, in intra-action, made possible stitching the group together in newly generative ways. Though Janna had not agreed with Grace, she had acknowledged Grace's self-risk and vulnerability, and had offered pieces of herself in response. Cutting together/apart, Grace offered yet more of her own self to the group, sharing with them her survival and newfound strength "as a sexual assault victim." In response, Valencia added suturing threads of self and experience, sharing with the others her own identity as an assault survivor. Yvonne joined Valencia, threading more loops through the sutures, emphasizing to the group, "I love Valencia. I love her. And, I think if women came together and supported one another...felt affirmed...had someone just to talk to, to listen to...it's all about love."

This moment in the focus group was one of dramatic cutting together/apart. Each woman claimed specific intersectional positions, in initially stable ways, that might have separated her from the others, and Grace even asserted that her identities necessarily ripped her from the shared group fabric. She understood herself simply as cut apart. It was the focus group intraactions themselves that made the intersections that they shared intra-sectional, cutting together/apart. A key element of (wo)monstrous work is to "experiment with different possible ways to connect, playing at all matter of errant wanderings in a virtual exploration of diverse forms of coupling and dis/connected alliance" (Barad, 2015, p. 387). The intra-sections the women negotiated provided the focus group ways to wander through explorations of how that they might understand, connect, and cut/mend together the fabric that Grace had assumed (and may well still assume) was rended apart.

\section{Chimeras: Collaging the (Wo)Monstrous Together/Apart}

Following the focus group discussion, the participants gathered around a large sheet of craft paper. Each woman had been asked to bring an object to her individual interview that she believed represented her doctoral experiences, and the women's contributions to the collage began with incorporating printed images of those objects (see Figure 1). We posed the following prompt to the women: "How does your identity as a woman doctoral student connect with [...] broader political and social 
conversations and movements? And how do you see yourself connecting to the other women here today?" As we, the researchers, observed the women working, we noticed that their initial contributions to the collage-much like the focus group-began with each emphasizing their unique perspectives and objects. Each participant established a space on the paper where her individual image and thoughts went, presumably cutting apart threads that had woven the group together during their discussions, as they dissected the paper with their additions.

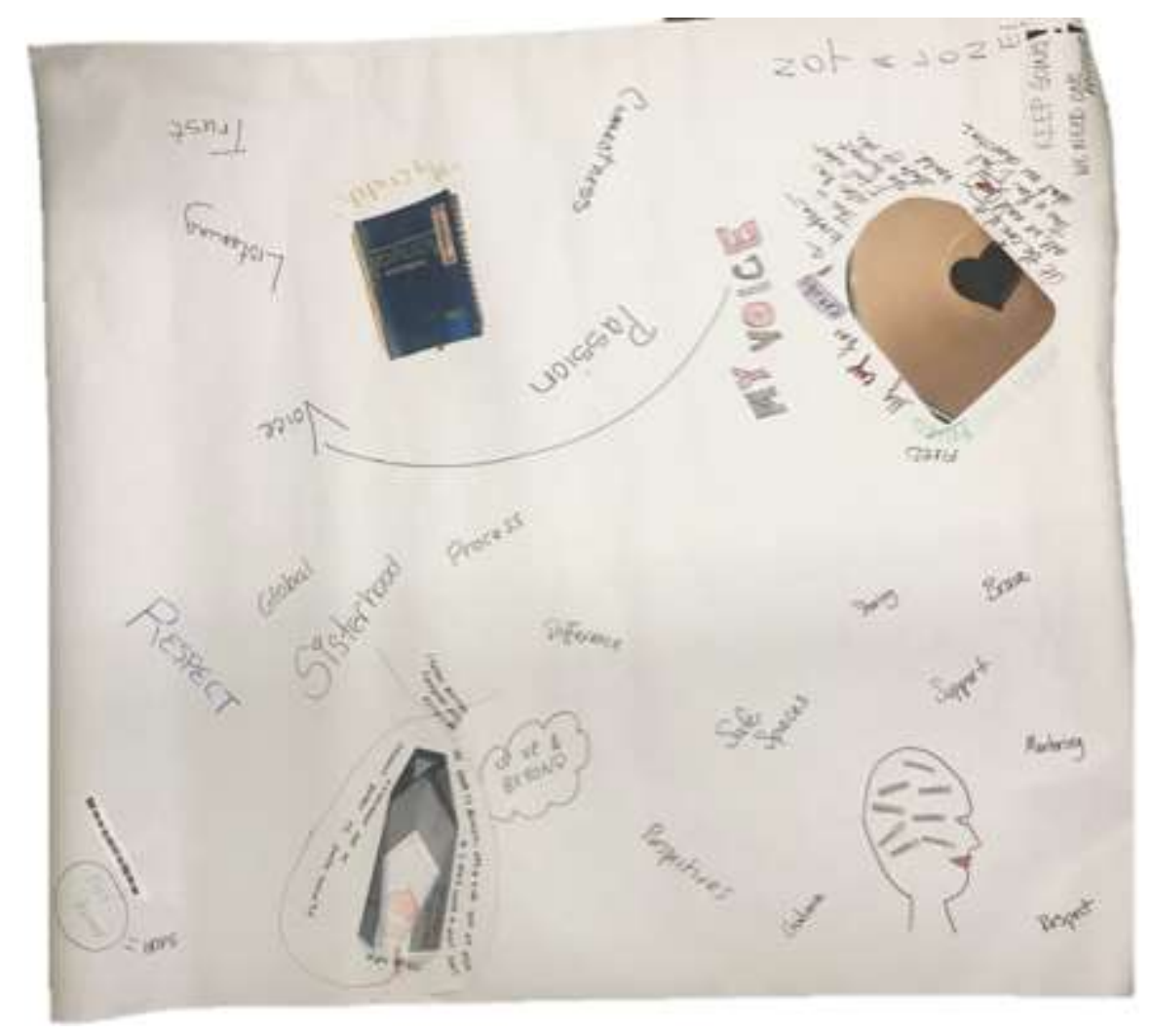

Figure 1. Collage. 
As the women noted what others were contributing, they began to explore what Barad (2015) called "the materiality of imagining together" (p. 388). The (wo)monster is "promiscuous and inventive in its agential wanderings" (p. 387), and around the paper, cutting together/apart became literal (even as it was always/already material). Scissors cutting, glue pasting, relations flowing, collapsing the previous boundaries through a (wo)monstrous co/creation. The women cut together/apart encounters, objects, stories, and experiences, producing a "patchwork, a suturing of disparate parts" (p. 393) that visually reflected their together/apart doctoral journeys. Then, these (wo)monsters abandoned their starting points and literally wandered to others' spaces, adding text, crossing through and illustrating their own and others' words, and drawing lines and arrows that, while bisecting sections, sutured concepts and concerns together. In doing so, their "movement [became] generative as it enclose[d] and invest[ed] in a new space [with...] new boundaries, and shedding" (pp. 413-414) the momentary segmentations that had begun their work. A (wo)monstrous chimera was co/created, a she-monster of incongruous parts that reverberated with possibility and connection.

The images retained their individual origins while (wo)monstrously suturing together new parts and new, collective meanings. For example, Valencia had added an image of a chipped cup to represent her doctoral journey, emphasizing her individual struggle with "keeping my cup from emptying, keeping it full for myself" as a student, researcher, mother, and daughter. She wrote around the close-up of the image, "My cup has cracks and is broken-This is also how I feel about the current state of the world." Another woman, after considering Valencia's image and text, wrote alongside in all caps: "NOT ALONE!!! KEEP GOING! WE NEED ONE ANOTHER!" (see Figure 2). Another wrote "MY VOICE" above the cup's image, to both acknowledge the image serving as a way for Valencia to speak, and, as she verbally explained to the group, to indicate the ways that Valencia's initially separate contributions added to and reflected her own efforts to speak and be heard. Another drew a heart in the center of the cup and both marked through Valencia's word "love" and highlighted it in red to, as she explained, reflect the brokenness of self and the world, and to emphasize the scarcity but importance of love. One woman wrote beside the cup, "NEEDS TO BE FILLED" to reflect Valencia's emphasis on keeping her cup/self full, while another marked through "FILLED" and wrote "FIXED," because, she explained, "that's what other people think needs to happen - that we need to be 'fixed' because 'filled' is selfish." 


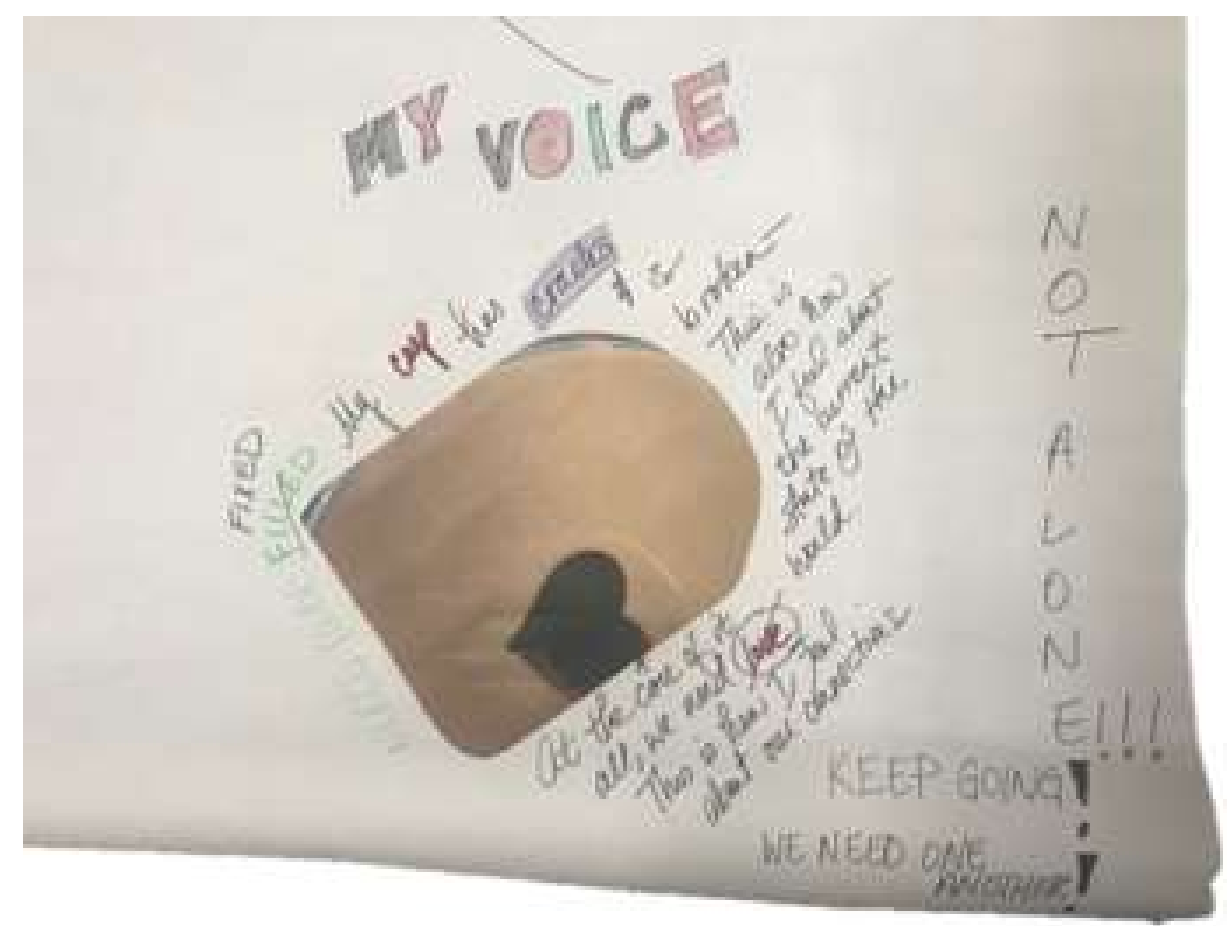

Figure 2. Not Alone.

As researchers we had initially imagined this intra-action as collage-making. We had envisioned bringing together an assemblage of disparate images that the group would create into a new whole (e.g. Butler-Kisber, 2008; Osei-Kofi, 2013). The women, however, created monsters through their intra-actions, their creative process, and the group-produced collage.

Through (wo)monstrous intra-actions, organic, living, meaningful amalgams; beautiful, empowering, together/apart creatures were born. The (wo)monsters had birthed "chimeras - cross-species cross-kind mixtures-made of [...]

configurations/reconfigurations of disparate kinds" (Barad, 2015, p. 401). Chimeras in Greek mythology are she-monsters, made of the incongruous parts of lions, goats, and serpents, yet materializing as a whole, a fire-breathing entity (Chimera, n.d.). In the collaging process, the women played with both their intra-sectionality and their incongruity, creating a visual work that 
celebrated the multiplicities of being/doing, melding the women's identities, perspectives, words, images, and voices. In this instance, Valencia shared a sense of brokenness as a woman of color who felt emptied by the tensions between her academic and personal selves. Rather than her image and text becoming solely her intra-sectional expressions, her chipped cup served as a structure upon which all of the participants "sutured together uncanny configurations" that honored her/themselves/others, while critiquing the forces that they felt oppressed her/them/others (Barad, 2015, p. 401). The point of collage-making for the women was the monstrous, chimerical co/creation of cutting/drawing/writing together/apart.

\section{Becoming (Wo)Monstrous}

I offer you this warning: the Nature you bedevil me with is a lie. Do not trust it to protect you from what I represent, for it is a fabrication that cloaks the groundlessness of the privilege you seek to maintain for yourself at my expense. (Stryker, 1994, pp. 240-241)

Stryker's rejection of social norms signals, for Barad (2015), an "embrac[ing of] the would-be epithet of monstrosity, harnessing its energy and power to [... ] self-affirmation" (p. 392). It is the refusal to be fabricated according to social norms that provides agency and challenges the structures that privilege some at others' expense. In the first large focus group, we three experienced (wo)monstrous intra-actions in which the women, as individuals, considered themselves in relation to politics, identities, and outside forces always/already at work in the women's lives. The second large focus group dialogue continued discussions of race, moving toward a more collective discussion focused on gender and affirmation. It became a site where women agentively cut selves/others together/apart from the normative fabrications that Stryker and Barad critique; they rebirthed themselves as collective- and self-affirmingly (wo)monstrous.

The second focus group was held at the time convenient to the most schedules and brought together a larger and more diverse group than the first. Four of the eight identified as Black women and four as White; three were notably older than the other women; four were married; three were mothers; and one participant and one researcher were visibly pregnant. Meanwhile, several women intra-sected multiples of these categories. As we prepared to facilitate this focus group, we were unsure of how these multiplicities would matter, and how/if the group would find ways to connect and share as the previous group had. After brief introductions by each woman, the focus group quickly found a common thread through their discussions of their doctoral programs' influences on their identities as women. Tamara told the group, 
I operate in Black Feminist thought. Prior to graduate school, I never really thought about my womanhood. It just wasn't salient to me. I thought about my Blackness, but not gender and women's rights. [...] the womanhood part of it-l've thought about that more lately [because of doctoral studies].

Following a brief pause, Tiffany built on Tamara's assertion and continued,

Your identity impacts your research at all times. [...] As a woman, it allows-especially being a Black woman-my story. As a Black woman especially, in this societal context, my race goes before my womanhood [in terms of others' assumptions], and I have to choose. [...] The doctoral program is going to teach you about yourself. I'm learning more about being a woman, along with the intersectional identity of being a Black woman.

Once Tamara and Tiffany introduced the concept of intersecting identities, the group's dynamics became notably intrasectional. Several White participants noted the problematic nature of this shift, in that participants of color had been left to introduce these elements. Anna, for example noted that "research feels gendered," but that despite those sites of oppression, her Whiteness afforded her forms of privilege that she had never questioned before her doctoral program. She said to the group, "To read Black Feminist scholars, it's like, 'Oh, my gosh, here's these things I've never had to consider,'” to which Raquel responded, "Well, I've considered it. I've lived it." Anna acknowledged, "You're absolutely right, and I need to be more aware, too." In response, Tamara thanked Anna and said, "You know, I've had my own critical moments in this doctoral program." As the women spoke, the others leaned forward in their seats, eagerly engaged, readily acknowledging their own shortfalls and the importance of their and others' lived experiences. The entire circle crackled with energy, and the women's thoughts and experiences entangled to celebrate intersectionality intra-sectionally, with ready exploration of oppression and privilege. Women examined race, socioeconomics, motherhood, and marriage, with all participants engaging. The group's exploration of academia as both gendered and racialized became a common thread.

As the women continued tugging the threads of gender and race, knitting themselves together more tightly, they began a collective cutting together/apart. This collective tearing/suturing was notably different from the first focus group which had developed along individual threads. Centering their identities as women, the participants took turns splaying their gendered lives open for the group, examining the ways that social conditioning had shaped their navigations of doctoral programs. 
Tamara, who had begun weaving the uniting thread of intersectionality, also initiated the cutting. She shared with the group an uncomfortable conversation that she had had with a man she had previously imagined herself marrying:

I had a really critical moment recently. My "friend" [at her teasing emphasis on the word, other participants laughed and shook their heads with smiles] is working on his PhD, too, and we were talking about writing together, [...] so then I was thinking about publishing with my last name, "Springtowne." And he put himself as first author, and I was like, "Nuh-uh! No. Wait a minute," and it opened up this conversation of when I get married, like, do I publish under my name? Do I need to hyphenate my name?

Raquel immediately interjected, "You're gonna publish in your last name!", while Tiffany asked Tamara, "What do you want?" The consideration of how to name one's self relative to academic publishing was, the group decided, "not a man issue" because "men don't have to think about that." Like Stryker, whose rejection of "bedeviling" norms began this section, the women worked to dissect gendered expectations and, together cut themselves apart from previously taken-for-granted gendered actions/expectations.

These intra-actional cuttings emphasized the ways that the individuals/group extracted and excised expectations that demanded that they, as the participants phrased it, "give up certain parts" of themselves. And, in "choosing not to do things" and noting that those cuts and refusals were "inherently gendered," they created a new space where they could define and describe themselves on their terms. Mutually supporting one another, they cut together, simultaneously cutting apart and discarding the range of expectations that required that they sacrifice parts of themselves. These cutting together/apart moments served as "a sewing together of individual bits and pieces [...] that always already holds together" (Barad, 2015, p. 406).

May, contributing to the group's cutting/suturing, shared with the others that she "was going back" with her surname. May expressed, "[I've] been married six years, and I took my husband's [last] name, I'm at least going to hyphenate it now." She shared with the others that her husband would object to her doing so, but that hyphenating was her decision. In response, Anna shared, "I want to hold on to every bit of my life," and that she, too, had taken her husband's last name when she had married, but, she explained, as an act of resistance against being fully absorbed into her husband's identity, she had begun to include her pre-marriage surname in all academic documents, "so that that piece of me is still there." Other women offered ways that they 
did or would (re)configure themselves to be more for them and less for others, (wo)monsters imagining and (re)creating new ways of being, knowing, and relating. May summed up the shared (re)configurations of cutting together/apart and suturing, suggesting that they were "always becoming," and that she [May] was "becoming differently than I was."

Following the verbal cutting and (re)/(dis)membering, the women moved to a table holding a large sheet of craft paper. Similar to the first group, each woman began individually cutting, writing, pasting, or marking a bounded area. After several minutes of working, glue sticks and oil pastels scattered around the table, each of the eight had individually contributed to a collage that visually (re)presented their experiences as women doctoral students. There was a (re)collective pause in the group's talk and art, a preemptive moment, indicating that they were "done." But after a brief pause, Raquel picked up a light blue oil pastel and began marking between the women's individual images and words. Puzzled, Tiffany asked, "What are you doing?" to which Raquel replied, "We need to connect this. They're pieces that connect." As Raquel worked, she remarked to the group that the center of the paper was empty. Tiffany agreed, "Yeah, there's nothing to connect all of us." Grabbing a pair of scissors, Anna responded, "I got this" and cut a section from one corner that read "Woman Stuff," moving it to the center (see Figure 3). As they had during their talk, the women began to suture the images together to (re)create/(re)member anew. Others smiled in appreciation and several commented, "Great job," while the ones closest to May began to help tape it down. Raquel continued her markings to ensure that this addition was encompassed into the connected whole. 


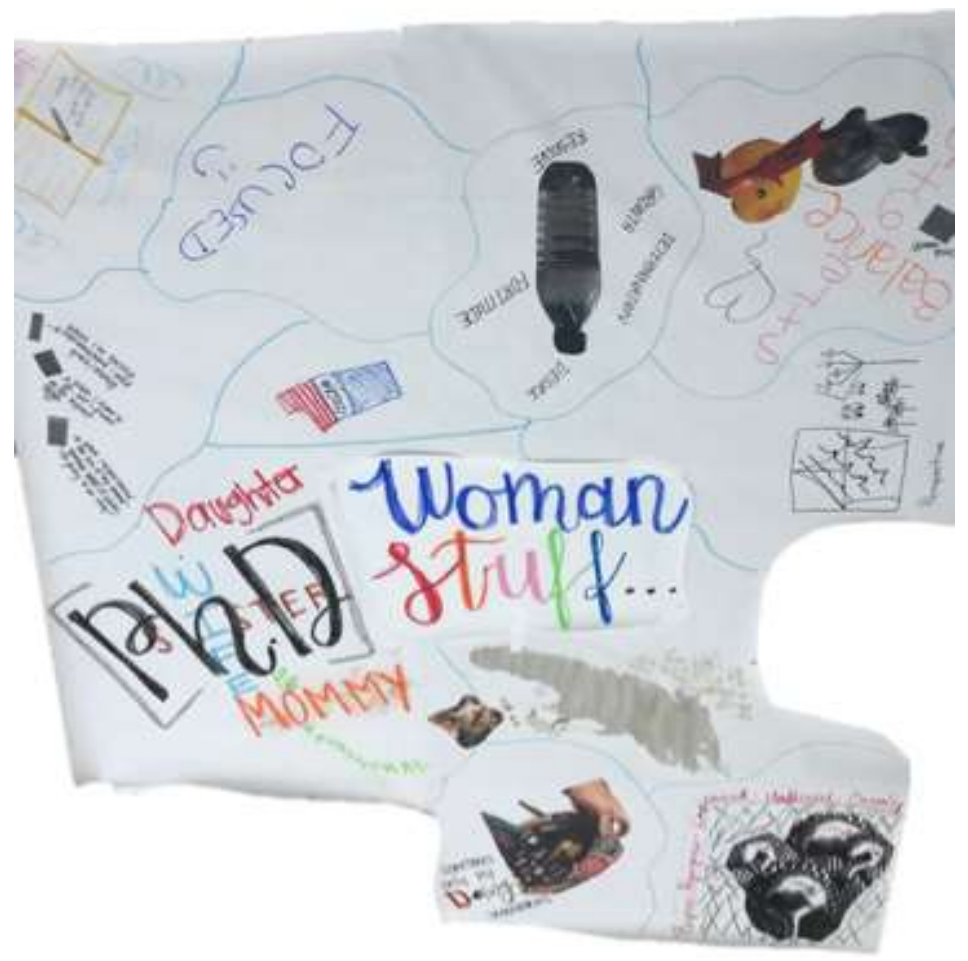

Figure 3. Woman Stuff.

After a flurry of cutting, taping, writing, and laughter, the group paused again, before they began to talk through how they had contributed to the collage and how they understood the art/making as connected to the previous discussions. May told the group that, initially, she had included a picture of her planner because it was integral to her doctoral studies, but that now the image was also a book because of her new appreciation for "sharing our stories" and "greater aspirations to change things [relative to being women in academia]." This shift was inspired by the collective trust engendered from the others' openness during the focus group and collaging. Sally, a married White woman with children, noted that after the groups' intra-actions, "my perspective has changed so much. [...] The White woman. The Black woman. The Black man. Everything that they have to go through to get to the same spot [as a White man]." She then added that "I want my kids to be educated enough" to 
understand sexism and racism. (Wo)monsters, shifting, reconfiguring, imagining new and different futures of radical connection and relation, cutting together/apart.

May's and Sally's comments emphasized the intra-sectionalities within the group. May's statement acknowledged the gendered/normative forces that entangled all of the women, while expressing her (wo)monstrous desire to overturn those norms that shaped her and the others' lives, academics, and everyday interactions. Sally's reflexivity on issues of race and gender reflected the degrees to which others' intersectional identities had become intra-sectional- appreciating others' perspectives as part of shifting her understandings of self, society, academia, and motherhood. In these and innumerable other moments, the women's (re)membering "trac[ed] entanglements, responding to yearnings for connection" (Barad, 2015, p. 407), both literally drawing connecting lines through the creation of the collage, and emphasizing the forms of intra-connectedness that they had found through the group. Becoming (wo)monstrous together/apart. Toward the end of the group's meeting, as the eleven of us, participants and researchers, stood around the collage, May intentionally spilled water and food on the collective work. When others wondered aloud why she had done so, she emphasized, " $Y$ 'all, this work [being a woman in academia] is messy." She and others then began to overlap words and identities over various sections of the paper, such as boldly marking "PhD" on top of another's words "WIFE," "SISTER," and "MOMMY" (see Figure 4). Barad (2015) similarly notes that these entangled and intra-secting identities/demands are messy. The "agential capacities for [...] imagining together" is non-linear, jumbled, and unwieldy (Barad, 2015, p. 388). 


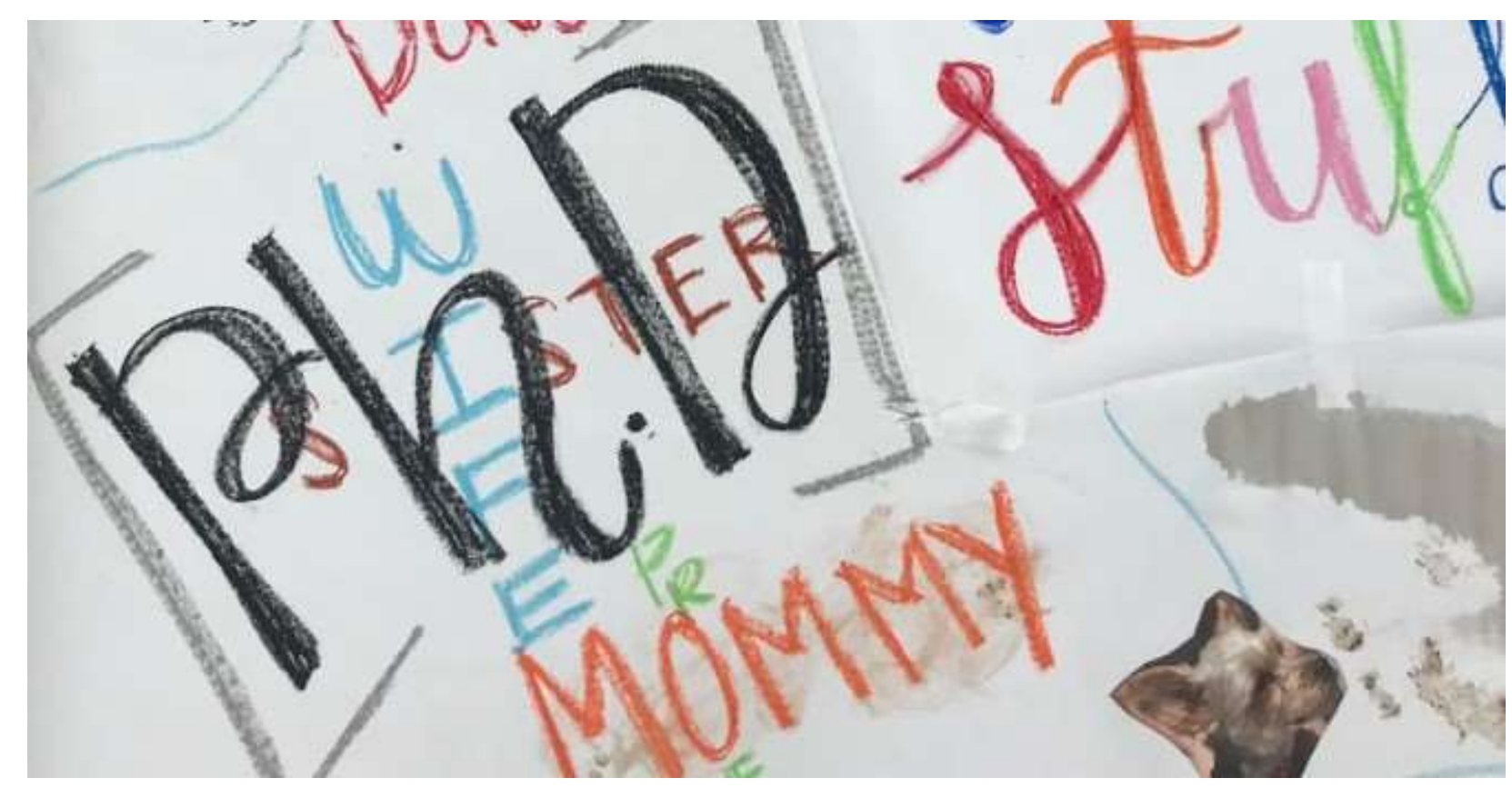

Figure 4. Wife. Sister. Mommy.

The making of (wo)monsters is, indeed, entangled and untidy work. Decisions such as celebrating womanness along with Blackness, dropping/adding-to a husband's surname to reclaim one's self, and choosing to have motherhood intra-sect with gender/race are decisions that, like Stryker's (1994), reject the "fabrication[s]" and "privilege" that Whiteness and masculinity "maintain [...] at my expense" (pp. 240-241). These efforts require chopping away vestigial appendages crafted in patriarchy and racism to realize "the promise of monsters" and (wo)monsters" "monstrous re/generations" and "radical im/possibilities" (Barad, 2015, p. 407). Thus, the focus group participants sought to cast away some expectations, such as dissolving their names within another's, while simultaneously demanding that they acknowledged the inevitable/constant overlap of others' expectations. For example, "PhD" existing with/in motherhood and marriage, or within the privileges associated with advanced education cutting together/apart between the intersections of gender and race. As we researchers began to close the group's meeting, Raquel shared that the process, for her, had emphasized the importance of "learn[ing] how to do things 
better/differently." Tamara reflected, "This community of women that I've built here [in her doctoral program and the research intra-action], it's helped me, and it was unexpected. And, I've certainly found it in this experience, this whole experience, this group of women means a lot." Barad noted, "The promise of monsters is a regenerative politics, an invitation to explore new ways of being [...] new forms of becoming, new possibilities for kinship" (p. 410). The (wo)monsters found new possibilities, agency, and resolve-while forming new intra-relationships through their cutting together/apart.

\section{Becoming (Wo)Monstrous: Vulnerability and Limitations}

We three were genuinely humbled and moved by the degrees to which these women opened themselves for self/group cutting together/apart. Becoming (wo)monstrous "gives birth to new modes of generativity" but involves vulnerability (Barad, 2015, p. 393). Cutting together/apart was agentive and supportive for these women, at the same time as these psychic/emotional/social cuts were like physical ones, in that they left marks; they sometimes hurt. Grace's trembling hands and reddened chest during the first focus group, prior to sharing her political affiliations as exclusionary/different, were a physical embodiment of this hurt.

Valencia, in a trembling voice and with balled hands, told the group near the end of the intra- action,

[Before I arrived,] I didn't know if I was going to participate. I didn't know if I was going to be truthful. [...] There's not a lot of people in my outside world who understand [what earning a PhD involves]. [...] I got a lot of judgment [about being a woman of color]. It shut me down.

The thickness of her voice and the hesitations in her speech indicated the internal hurts, as her balled-up hands communicated the physical toil of her experiences-and her participation in the focus group.

Barad and Stryker describe the making of agentive monsters as inevitably painful and vulnerable-not because of the physicality of the cutting/sewing, but because of the dehumanizations that make beings such as (wo)monsters necessary. Stryker (1994) described efforts to transpose society's monster-making-constructed through oppressive norms-with a self-birthed monster. The creation/birth of the (wo)monster involves "flesh torn apart and sewn together again" in new forms, rejecting/refusing the shape/constraints/norms "in which it was born" (p. 251). Reconceptualizing feminist research to include the (wo)monstrous necessitates acknowledging and exploring the possibility that participants' willingness to be a part of a project is to open themselves up to be vulnerable and to be hurt. The cutting together/apart and suturing processes made their participation 
powerful, meaningful, and rewarding for these (wo)monsters, but to ignore the pain of that the cutting/sewing would also ignore the degrees to which that pain provided response-ability for them, and a sense of responsibility and gratitude for us as researchers.

In the midst of this powerful generativity, however, there were limitations. We had hoped to have a diversity of womanidentifying participants, and while those who helped to generate this research offered ranges of perspectives, there were certainly excluded voices. For example, all of these participants studied in social sciences or humanities fields, which tend to be women- dominated disciplines; inevitably, women from STEM fields would have had much to offer on the gendered natures of their doctoral programs. Additionally, while one researcher, Stephanie, identified as a queer lesbian, no LGBTQIA+ women enrolled in the study. Though the implications of cisheteronormativity shaped everyone's everyday intra-actions, and the group did acknowledge LGBTQIA+ individuals in their discussions, those conversations were not humanized and fleshed out in ways that others were. These 19 women and we three researchers were ultimately only able to cut and suture those experiences that were ours, and unfortunately, doing so left many perspectives and identities on the cutting room floor.

\section{Conclusion: Self-Birthing (Wo)Monsters}

However, despite its limitations, the (wo)monstrosity of this research was palpable and undeniable. These women's experiences and our (wo)monstrous effort to explore identities within higher education offer incredible potential for research methods and higher education praxes. Our efforts to include these women in the entirety of the research, from its inception into the present, with this paper, are practices that move beyond the standard "member checking" efforts into a deliberate effort to not just include, but to involve participants. We know that it sounds near-impossible, but there were no moments of lasting dissonance in these large focus groups or in the participants' engagement with this paper. We have not focused on positive intra-actions to create a utopic, Pollyanna version of these research intra-actions. The women co-created beautiful, calming, welcoming spaces, even as they co-navigated disagreements and tensions. Certainly, we researchers have facilitated focus groups that went "sideways," so to speak, but such simply did not happen here. They readily pulled us into the research intra-actions, and then questioned us during our analyses and writing, always in ways that were supportive and empowering for them and us. In adopting an ethico-onto-epistemology, neither they nor we were ever neutral entities in the research, so when potential ruptures happened- such as Grace's hesitation and fear in deviating from the group - the participants actively confronted those breaches intra-actively. Part of making monsters is, in fact, acknowledging and celebrating the messiness. They and we 
plunged our hands into those bleeding cuts and binding threads, constantly acknowledging our (co)creations, and suturing the rips and tears together in new ways.

When examining their situatedness in higher education, a common concern from the participants was the dilemma of (in)visibility. The theorization of (wo)monsters centers individual/group agency in ways that might inform efforts to effect equitable classroom praxis. These women's stitching and cutting happened over the course of a single research project: consider the potential of intra-sectional ethico-onto-epistemological approaches with a group that meets regularly, perhaps because of coursework or committee efforts. The women and we left feeling visible, feeling heard, feeling powerful. As the first large focus group concluded, Valencia remarked to the other women, "Man, that felt great! And, I was one of those who said I almost didn't want to come." At the end of the second one, Anna reflected on "the differences in who I was and who I'm becoming now," as Tamara celebrated the "community of women that I've built here [in her doctoral program, which she emphasized included those in the research intra-action]."

As the large focus groups concluded, the women were well aware of the ways that they had individually/together accomplished "the hard work of constituting ourselves on our own terms, against the natural order" (Barad, 2015, p. 393). The reconfiguring of self, of woman, of (wo)monster, and of research "gives birth to new modes of generativity" and is a form of self- birthing that is always/already "an originary birthing [...and] a rebirthing" (Barad, 2015, p. 393). Anna described herself and the others as "becoming differently," a process through which she and the others were always/already (re)constituting themselves. They sorted through remnants of who they were/had been, including surnames, political and religious affiliations, and various relationships; in doing so, they (re)birthed themselves on their terms, for themselves, even while still/always negotiating the gender norms that continued to work to crush and mold them, in academia and beyond. Those burdens, however, were not as heavy as they had been before. The (wo)monsters were new beings, born/constructed from "fleshy possibilities" and newly found/articulated agency (Barad, 2015, p. 416). As a newly (re)birthed creature, each (wo)monster moved forward with collective strength and resolve, more powerful than any individual participant or researcher. Together, these women and we switched off the room lights, and in that darkness "surge[d] forth electrifying the field of dreams," to craft/birth/empower new (wo)monsters and to continue to reshape academia and research. 


\section{Acknowledgements}

We are ever grateful to the (wo)monstrous women who participated in this study. Thank you for your time, your vulnerability, and your inspiration.

\section{References}

Abetz, J. S. (2016). "You can be anything but you can't have it all": Discursive struggles of career ambition during doctoral candidacy. Western Journal of Communication, 80(5), 539-558. https://doi.org/10.1080/10570314.2016.1186825

Angervall, P., \& Silfver, E. (2019). Assembling lines in research education. Studies in Graduate and Postdoctoral Education, 10(2), 142-154. https://doi.org/10.1108/SGPE-03-2019-0028

Aryan, B., \& Guzman, F. (2010). Women of color and the PhD: Experiences in formal graduate support programs. Journal of Business Studies Quarterly, 1(4), 69-77.

Batruni, C. W. (2018). The Beirut College for Women and the transformation of women's higher education in Lebanon. Theological Review, 39(2), 75-99.

Barad, K. (2007). Meeting the universe halfway: Quantum physics and the entanglement of matter and meaning. Durham, NC: Duke University Press. https://doi.org/10.1215/9780822388128

Barad, K. (2010). Quantum entanglements and hauntological relations of inheritance: Dis/continuities, spacetime enfoldings, and justice-to-come. Derrida Today, 3(2), 240- 268. https://doi.org/10.3366/drt.2010.0206

Barad, K. (2013). Ma(r)king time: Material entanglements and re-memberings: Cutting together apart. In P. R. Carlile, D. Nicolini, A. Langley, \& H. Tsoukas (Eds.), How matter matters: Objects, artifacts, and materiality in organization studies (pp. 1631). Oxford, UK: Oxford University Press. https://doi.org/10.1093/acprof:oso/9780199671533.003.0002

Barad, K. (2014). Diffracting diffraction: Cutting together-apart. Parallax, 20(2), 168-187. https://doi.org/10.1080/13534645.2014.927623

Barad, K. (2015). Transmaterialities: Trans*/Matter/Realities and queer political imagining. GLQ: A Journal of Lesbian and Gay Studies, 21(2-3), 387-42. 
Bireda, A. D. (2015). Challenges to the doctoral journey: A case of female doctoral students from Ethiopia. Open Praxis, 7(4), 287-297. https://doi.org/10.5944/openpraxis.7.4.243

Butler-Kisber, L. (2008). Collage as inquiry. In J. G. Knowles \& A. L. Cole (Eds.), Handbook of the arts in qualitative research: Perspectives, methodologies, examples, and issues. (pp. 266-275). Thousand Oaks, CA: SAGE Publications.

Catterall, K., Mickenberg, J., \& Reddick, R. (2019). Design thinking, collaborative innovation, and neoliberal disappointment: Cruel optimism in the history and future of higher education. Radical Teacher, (114), 34-47. https://doi.org/10.5195/rt.2019.548

Chimera. (n.d.). Merriam-Webster Online. In Merriam Webster. Retrieved 30 April 2019 from https://www.merriam-webster.com/dictionary/chimera?utm_campaign=sd\&utm_medium=serp\&utm_source=jsonld

Crenshaw, K. (1989). Demarginalizing the intersection of race and sex: A Black feminist critique of antidiscrimination doctrine, feminist theory, and antiracist politics. University of Chicago Legal Forum, 8(1), 139-167.

Crenshaw, K. (1991). Mapping the margins: Intersectionality, identity politics, and violence against women of color. Stanford Law Review, 43(1241), 1241-1298. https://doi.org/10.2307/1229039

Crenshaw, K. (2004). Intersectionality: the double bind of race and gender. Perspectives, Spring. Retrieved from www.americanbar.org/content/dam/aba/publishing/perspectives_magazine/women_perspectives_Spring2004Crensha wPSP.authcheckdam.pdf

Grant, C. M. (2012). Advancing our legacy: A Black feminist perspective on the significance of mentoring for African-American women in educational leadership. International Journal of Qualitative Studies in Education, 25(1), 101-117. https://doi.org/10.1080/09518398.2011.647719

Grant, C. M., \& Simmons, J. C. (2008). Narratives on experiences of African-American women in the academy: Conceptualizing effective mentoring relationships of doctoral student and faculty. International Journal of Qualitative Studies in Education, 21(5), 501-517. https://doi.org/10.1080/09518390802297789

Gregor, M. A. (2015). The changing face of psychology: Leadership aspirations of female doctoral students. Counseling Psychologist, 43(8), 1090-1113. https://doi.org/10.1177/0011000015608949

Halberstam, J. (1995). Skins shows: Gothic horror and the technology of monsters. Durham, NC: Duke University Press. https://doi.org/10.1215/9780822398073

Haraway, D. (2008). When species meet. Minneapolis, MN: University of Minnesota Press.

Haraway, D. (2016). Staying with the trouble: Making kin in the Chthulucene. Durham, NC:

Reconceptualizing Educational Research Methodology 2019, 2,3(2) Special Issue

https://journals.hioa.no/index.php/rerm/issue/view/397 
Duke University Press. https://doi.org/10.1215/9780822373780

Holley, K. A. (2015). Doctoral education and the development of an interdisciplinary identity. Innovations in Education \& Teaching International, 52(6), 642-652. https://doi.org/10.1080/14703297.2013.847796

Holm, J. M., Prosek, E. A., \& Godwin Weisberger, A. C. (2015). A phenomenological investigation of counseling doctoral students becoming mothers. Counselor Education and Supervision, 54(1), 2-16.

Kelly, B., \& McCann, K. (2019). Women faculty on the tenure track: The compounding role of being the breadwinner. Journal of the Professoriate, 10(1), 73-109.

Khattak, S. S. G. (2018). Hearing silent voices and listening to perceptions and experiences of Pukhtun women on higher education opportunities for women in Pakistan. Journal of Women's Studies, 25(1), 35-58.

Kurtz-Costes, B., Helmke, L. A., \& Ulku-Steiner, B. (2006). Gender and doctoral studies: The perceptions of Ph.D. students in an American University. Gender \& Education, 18(2), 137-155.

Kyodo. (2018, March 24). 88-year-old woman becomes oldest person in Japan to earn doctoral degree. The Japan Times. Retrieved from https://www.japantimes.co.jp/news/2018/03/24/national/88-year-old-becomes-oldest-earn-doctoraldegree-japan/\#.XMsf-qZ7nJx

Magano, M. D. (2011). Narratives on challenges of female Black postgraduate students. Teaching in Higher Education, 16(4), 365-376. https://doi.org/10.1080/13562517.2010.546523

Marbley, A. F., Wong, A., Pratt, C., Jaddo, L., Santos, \& Hatchett, S. L. (2011). Women faculty of color: Voices, gender, and the expression of our multiple identities within academia. Advancing Women in Leadership, 31, 166-174.

Mansfield, K. C., Welton, A., Lee, P.-L., \& Young, M. D. (2010). The lived experiences of female educational leadership doctoral students. Journal of Educational Administration, 48(6), 727-740. https://doi.org/10.1108/09578231011079584

McKinley, B.-D. (2014). Negotiating (il)legible identities: On being a Black female "Professor in Training." Sociological Imagination, 50(3), 30-49.

Miller, M. (2016, April 15). Taking on the PhD later in life. The New York Times. Retrieved from https://www.nytimes.com/2016/04/16/your-money/taking-on-the-phd-later-in-life.html

Morley, L. (2013). The rules of the game: Women and the leaderist turn in higher education. Gender \& Education, 25(1), 116131. https://doi.org/10.1080/09540253.2012.740888

National Science Foundation (2018, March). 2016 Doctorate recipients from U.S. universities. (Report No. 18-304).

Reconceptualizing Educational Research Methodology 2019, 2,3(2) Special Issue

https://journals.hioa.no/index.php/rerm/issue/view/397 
Osei-Kofi, N. (2013). The emancipatory potential of arts-based research for social justice. Equity \& Excellence in Education, 46(1), 135-149. https://doi.org/10.1080/10665684.2013.750202

Pope, E. C., \& Edwards, K. T. (2016). Curriculum homeplacing as complicated conversation: (Re)narrating the mentoring of Black women doctoral students. Gender \& Education, 28(6), 769-785. https://doi.org/10.1080/09540253.2016.1221898

Shelton, S. A. \& Flint, M. A. (2019a). The spacetimemattering and Frankenstein-esque nature of interview transcriptions. Qualitative Research Journal, 19(3), 202-212. https://doi.org/10.1108/QRJ-03-2019-104

Shelton, S. A. \& Flint, M. A. (2019). The value of transcription in encouraging researcher reflexivity. SAGE Research Methods Cases, 1-11. https://doi.org/10.4135/9781526477705

Stryker, S. (1994). My words to Victor Frankenstein above the Village of Chamounix. GLQ: A Journal of Lesbian and Gay Studies, 1(3), 237-254. https://doi.org/10.1215/10642684-1-3-237

Turner, C. S. V. (2002). Women of color in academe: Living with multiple marginality. The Journal of Higher Education, 73(1), 7493 https://doi.org/10.1080/00221546.2002.11777131

Wolfinger, N. H., Mason, M. A., \& Goulden, M. (2009). Stay in the game: Gender, family formation and alternative trajectories in the academic life course. Social Forces, 87(3), 1591-1621. https://doi.org/10.1353/sof.0.0182

Yeh, T. (2008). A heuristic study on the leadership practices of female faculty in higher education. International Journal of Organizational Innovation, 11(2), 245-259.

Wu, Y. \& Wu, H. (2015). Higher education learning experiences among Vietnamese immigrant women in Taiwan. Adult Education Quarterly, 65(2), 133-151. https://doi.org/10.1177/0741713614566673

Zahneis, M. (2018, June 11). Women of color of academe make 67 cents for every dollar paid to white men. The Chronicle of Higher Education. Retrieved from https://www.chronicle.com/article/Women-of-Color-in-Academe-Make/243636.

Reconceptualizing Educational Research Methodology 2019, 2,3(2) Special Issue

https://journals.hioa.no/index.php/rerm/issue/view/397 
Table 1: Participants' multiple self-described identities.

\begin{tabular}{|c|c|c|c|c|c|c|c|}
\hline Name & $\begin{array}{l}\text { Large Focus } \\
\text { Group } \\
\text { Participation }\end{array}$ & Gender & $\begin{array}{l}\text { Racial and/or } \\
\text { Ethnic Identity }\end{array}$ & Sexuality & Parent? & $\begin{array}{l}\text { 40-years-old } \\
\text { or older }\end{array}$ & $\begin{array}{l}\text { Inter- } \\
\text { national } \\
\text { Student? }\end{array}$ \\
\hline \multicolumn{8}{|c|}{ Researchers: } \\
\hline Stephanie & Both & $\begin{array}{l}\text { Cisgender } \\
\text { woman }\end{array}$ & White & $\begin{array}{l}\text { Queer; } \\
\text { Lesbian }\end{array}$ & No & Yes & $\begin{array}{l}\text { n/a; Faculty } \\
\text { member }\end{array}$ \\
\hline Kelly & Both & $\begin{array}{l}\text { Cisgender } \\
\text { woman }\end{array}$ & White & Heterosexual & $\begin{array}{l}\text { Yes, } 2 \text { young } \\
\text { children }\end{array}$ & No & $\begin{array}{l}\text { n/a; Faculty } \\
\text { member }\end{array}$ \\
\hline Maureen & Both & $\begin{array}{l}\text { Cisgender } \\
\text { woman }\end{array}$ & White & Heterosexual & No & No & $\begin{array}{l}\text { No; now a Faculty } \\
\text { member }\end{array}$ \\
\hline \multicolumn{8}{|c|}{ Participants, all participant-assigned pseudonyms: } \\
\hline Adelaide & $\begin{array}{l}2^{\text {nd }} \text { focus } \\
\text { group }\end{array}$ & $\begin{array}{l}\text { Cisgender } \\
\text { woman }\end{array}$ & White & Heterosexual & $\begin{array}{l}\text { Yes, } 5 \text { adult } \\
\text { children }\end{array}$ & Yes & No \\
\hline Anna & $\begin{array}{l}2^{\text {nd }} \text { focus } \\
\text { group }\end{array}$ & $\begin{array}{l}\text { Cisgender } \\
\text { woman }\end{array}$ & White & Heterosexual & $\begin{array}{l}\text { Yes, } 2 \text { young } \\
\text { children }\end{array}$ & No & No \\
\hline Ashley & $\begin{array}{l}\text { Did not } \\
\text { participate }\end{array}$ & $\begin{array}{l}\text { Cisgender } \\
\text { woman }\end{array}$ & Black & Heterosexual & No & No & No \\
\hline
\end{tabular}

Reconceptualizing Educational Research Methodology 2019, 2,3(2) Special Issue

https://journals.hioa.no/index.php/rerm/issue/view/397 


\begin{tabular}{|c|c|c|c|c|c|c|c|}
\hline Grace & $\begin{array}{l}1^{\text {st }} \text { focus } \\
\text { group }\end{array}$ & $\begin{array}{l}\text { Cisgender } \\
\text { woman }\end{array}$ & White & Heterosexual & $\begin{array}{l}\text { Yes, } 2 \text { adult } \\
\text { children }\end{array}$ & Yes & No \\
\hline Heather & $\begin{array}{l}\text { Did not } \\
\text { participate }\end{array}$ & $\begin{array}{l}\text { Cisgender } \\
\text { woman }\end{array}$ & White & Heterosexual & No & No & No \\
\hline Hope & $\begin{array}{l}1^{\text {st }} \text { focus } \\
\text { group }\end{array}$ & $\begin{array}{l}\text { Cisgender } \\
\text { woman }\end{array}$ & White & Heterosexual & No & No & No \\
\hline Janna & $\begin{array}{l}1^{\text {st }} \text { focus } \\
\text { group }\end{array}$ & $\begin{array}{l}\text { Cisgender } \\
\text { woman }\end{array}$ & White & Heterosexual & $\begin{array}{l}\text { Yes, } 2 \text { small } \\
\text { children }\end{array}$ & Yes & No \\
\hline Leigh & $\begin{array}{l}\text { Did not } \\
\text { participate }\end{array}$ & $\begin{array}{l}\text { Cisgender } \\
\text { woman }\end{array}$ & White & Heterosexual & No & No & No \\
\hline Lily & $\begin{array}{l}\text { Did not } \\
\text { participate }\end{array}$ & $\begin{array}{l}\text { Cisgender } \\
\text { woman }\end{array}$ & $\begin{array}{l}\text { Native } \\
\text { American: } \\
\text { Cherokee }\end{array}$ & Heterosexual & $\begin{array}{l}\text { Yes, } 2 \text { small } \\
\text { children }\end{array}$ & Yes & No \\
\hline
\end{tabular}




\begin{tabular}{|c|c|c|c|c|c|c|c|}
\hline Maggie & $\begin{array}{l}\text { Did not } \\
\text { participate }\end{array}$ & $\begin{array}{l}\text { Cisgender } \\
\text { woman }\end{array}$ & White & Heterosexual & No & No & No \\
\hline May & $\begin{array}{l}2^{\text {nd }} \text { focus } \\
\text { group }\end{array}$ & $\begin{array}{l}\text { Cisgender } \\
\text { woman }\end{array}$ & White & Heterosexual & $\begin{array}{l}\text { Yes, } 1 \text { small } \\
\text { child }\end{array}$ & No & No \\
\hline Raquel & $\begin{array}{l}2^{\text {nd }} \text { focus } \\
\text { group }\end{array}$ & $\begin{array}{l}\text { Cisgender } \\
\text { woman }\end{array}$ & Black & Heterosexual & No & No & No \\
\hline Sandy & $\begin{array}{l}2^{\text {nd }} \text { focus } \\
\text { group }\end{array}$ & $\begin{array}{l}\text { Cisgender } \\
\text { woman }\end{array}$ & Black & Heterosexual & No & Yes & No \\
\hline Sally & $\begin{array}{l}2^{\text {nd }} \text { focus } \\
\text { group }\end{array}$ & $\begin{array}{l}\text { Cisgender } \\
\text { woman }\end{array}$ & White & Heterosexual & $\begin{array}{l}\text { Yes, } 2 \\
\text { adolescent } \\
\text { children }\end{array}$ & Yes & No \\
\hline Stacy & $\begin{array}{l}\text { Did not } \\
\text { participate }\end{array}$ & $\begin{array}{l}\text { Cisgender } \\
\text { woman }\end{array}$ & White & Heterosexual & No & No & No \\
\hline Tamara & $\begin{array}{l}2^{\text {nd }} \text { focus } \\
\text { group }\end{array}$ & $\begin{array}{l}\text { Cisgender } \\
\text { woman }\end{array}$ & Black & Heterosexual & No & No & No \\
\hline Tiffany & $\begin{array}{l}2^{\text {nd }} \text { focus } \\
\text { group }\end{array}$ & $\begin{array}{l}\text { Cisgender } \\
\text { woman }\end{array}$ & Black; & Heterosexual & No & No & No \\
\hline
\end{tabular}




\begin{tabular}{|c|c|c|c|c|c|c|c|}
\hline & & & $\begin{array}{l}\text { Jamaican } \\
\text { American }\end{array}$ & & & & \\
\hline Valencia & $\begin{array}{l}1^{\text {st }} \text { focus } \\
\text { group }\end{array}$ & $\begin{array}{l}\text { Cisgender } \\
\text { woman }\end{array}$ & $\begin{array}{l}\text { Multiracial; } \\
\text { Black }\end{array}$ & Heterosexual & $\begin{array}{l}\text { Yes, } 1 \text { adult } \\
\text { child }\end{array}$ & Yes & No \\
\hline Yvonne & $\begin{array}{l}1^{\text {st }} \text { focus } \\
\text { group }\end{array}$ & $\begin{array}{l}\text { Cisgender } \\
\text { woman }\end{array}$ & White & Heterosexual & No & No & Yes \\
\hline
\end{tabular}

